\title{
Egy online közösségi háló offline földrajza, avagy a távolság és a méret szerepének magyar empíriái
}

\section{The offline geography of an online social network: Hungarian empirics on the role of distance and size}

\author{
JAKOBI ÁKOS, LENGYEL BALÁZS
}

\begin{abstract}
JAKOBI Ákos: egyetemi adjunktus, Eötvös Loránd Tudományegyetem, Regionális Tudományi Tanszék, Budapest; soka@ludens.elte.hu LENGYEL Balázs: tudományos munkatárs, International Business School, Budapest; MTA Közgazdaság-és Regionális Tudományi Kutatóközpont, Budapest; lengyel.balazs@krtk.mta.hu
\end{abstract}

KULCSSZAVAK: online közösségi háló, kibertér, településméret, távolság, térbeli regresszió

ABSZTRAKT: Az információs és kommunikációs technológiákon alapuló információcserében napjaink vezető platformjai az online közösségi hálók, melyek a felhasználóik számára a helytől független társadalmi élet lehetőségét nyújtják. A legutóbbi kutatások ugyanakkor arra utalnak, hogy a felhasználók és online barátaik valós világbeli földrajzi helyzete mégis meghatározó a hálózati topológia formálódásában. Az online közösségi hálók így vélhetően egyidejűleg tükrözik a kibertér és az offline földrajz jelenségeit. Jelen tanulmány az online közösségi hálók e kétarcúsága alapján azt vizsgálja, hogy az offline világ tényezői miként határozzák meg az online közösségek terjedését és aktivitását a lokális szinten. A 2000-es években vezető magyar online közösségi háló, az iWiW 2008-as települési szintủ adatainak elemzésével arra mutatunk rá, hogy a felhasználói arány (a terjedést közelítő változó) pozitív összefüggésben van a településmérettel és a Budapesttől való földrajzi távolsággal. Másrészt viszont az átlagos kapcsolatszám (az aktivitást közelítő változó) a településmérettől függetlennek tűnik, és magasabb értékeket mutat az ország periferikus elhelyezkedésű térségeiben. Összességében a központhoz való földrajzi közelség serkentőleg hat az online közösségi hálók terjedésére, míg a bennük megmutatkozó aktivitás vélhetően független a távolságtól, sőt, talán a távolsággal arányosan nő az online platform késői életszakaszában.

Ákos JAKOBI: assistant professor, Department of Regional Science, Eötvös Loránd University, Budapest; soka@ludens.elte.hu

Balázs LENGYEL: research fellow, International Business School, Budapest; Research Centre for Economic and Regional Studies, Hungarian Academy of Sciences, Budapest; lengyel.balazs@krtk.mta.hu

KEYWORDS: online social network, cyberspace, settlement size, distance, spatial regression

ABSTRACT: There is an ongoing debate in recent literature about the importance of distance and other spatial characteristics in cyberspace. The main question is how geographies of the so-called offline world influence the formation of online society, while often also the effects of online

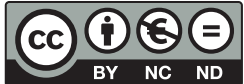


organisations on real geographies are in the forefront. Recent empirical results on cyberspace proximities, however, proved that relational proximities are important factors in the shaping up of internet infrastructure. In connection with this our paper intends to contribute to the discussion of distance effects by providing new insights on how internet has changed the role of spatiality. This is done by the analysis of virtual connections in cyberspace instead of the examination of the physical world's built up infrastructure.

Online social networks (OSN) are major platforms of ICT-enabled communication, supporting location-independent social life. However, recent findings suggest that the geographical location of users and their friends turns out to be a determining factor for network topology. Therefore, OSNs may be expected to bear features of cyberspace and offline geographies simultaneously. Our paper addresses this dual-faced phenomenon from a geographical perspective: how do offline factors shape spread of online communities and the local levels of activity in them? We collected settlement level data in 2008 about the iWiW, a leading OSN in the 2000' Hungary with more than 4 million users. Findings suggest that the user rate (proxy for spread) is positively associated with settlement size and geographical proximity of Budapest. On the other hand, the average number of connection values (proxy for activity) is independent from settlement size and is higher in peripheral regions of the country. It seems that the network spread is bound to locations, but once one is in the network, OSN tools help to conquer distance. In sum, proximity favours the offline spread of OSNs, while activity in these platforms might be independent of - or even favoured by - distance in a later stage of the online platform. Our findings also suggest that the bigger the settlement size, the higher the rate of registered citizens. On the contrary, the activity of OSN users measured by friendship ties is much less dependent from the settlement size.

\section{Bevezetés}

Emmanouil Tranos és Peter Nijkamp a Tér és Társadalomban megjelent írása (Tranos, Nijkamp 2013) abban a napjainkban széles körűvé váló vitában igyekszik állást foglalni, amely a távolság információs korbeli jelentőségét vagy jelentéktelenségét taglalja. Az immáron legalább másfél évtizedes diskurzus egyik oldala azzal az elméleti általánosítással él, mely szerint napjaink információs és kommunikációs technológiai (IKT) elemekkel átszőtt világában az új interakciós csatornák bárhová elérnek, bárhová képesek az új kor alapvető lételemének tekinthető információt továbbítani, s ennek következményeként a földrajz és a távolság jelentősége irreleváns, a távolság halott (Cairncross 1997). A többnyire filozófiai, társadalom- és gazdaságelméleti írásokkal ellentétben az infrastruktúra gyakorlati és empirikus oldalát vizsgáló területi kutatások egy része épp ellenkező következtetésekre jutott, s inkább azt valószínűsíti, hogy a földrajzi térnek és a távolságnak komoly, de legalábbis nem elhanyagolható szerepe van információs világunk valódi szerveződésében (de Blij 2007). Tranos és Nijkamp - habár cikkükben megjegyzik, hogy még nem rendelkezünk kellő empirikus tudással arról, hogy a távolság milyen szerepet tölt be a virtuális tér geográfiájában - a földrajzi távolságnak és a különböző kapcsolatiközelség-típusoknak az internet-infrastruktúra kiépülésére gyakorolt hatásait elemezve arra a megállapításra jutnak, hogy a távolság egyes formáinak kimutatható hatásai lehetnek világunkban. 
Jelen tanulmányunkban többek között ehhez a diskurzushoz kívánunk hozzászólni, hiszen Peter Nijkamp a Magyar Regionális Tudományi Társaság 2012. évi vándorgyülésén tartott előadásában is felhívta a figyelmünket arra, hogy újra kell értékelnünk a távolság halálával kapcsolatos nézeteinket (Nijkamp 2012). A konferencián tett hozzászólásainkban is arról kérdeztük az előadót, hogy vajon információs világunk mely dimenzióiban érvényesek ezek a kijelentések, s milyen vonásokban értékelődnek újra a térbeliség szerepei. A mai újszerü adatgyűjtési és adatfeldolgozási lehetőségek ugyanis újabb esélyt adhatnak egyes kapcsolódó kérdések megválaszolásához.

A következőkben többek között épp Tranos és Nijkamp eredményeire reflektálva magyarországi empíriákkal igyekszünk bizonyítani vagy cáfolni a távolság hatását, vizsgálatunkban ugyanakkor egy másik kulcsdimenzió, a méret szerepének feltárására is vállalkozunk, mivel mai világunk egyenlőtlenségi kutatásai gyakran az információs tér egy másik, ugyancsak jelentős térbeli sajátosságára, az agglomerációk hatásaira is felhívják a figyelmet (pl. Forman, Goldfarb, Greenstein 2005). Míg Tranos és Nijkamp vizsgálati eredményeiket az internetinfrastruktúra fizikai kapcsolatai, a geokódolt IP-kapcsolatok regionális szinten aggregált adatbázisa alapján fogalmazták meg, addig jelen kutatásunk az információs világ egy másik szférájában, a fizikai világban testet nem öltő virtuális tér hálózatainak elemzését célozza. Vizsgálatunk a hosszú ideig legnagyobbnak számító magyarországi online közösségi háló (online social network, OSN), az iWiW települési szintre aggregált 2008-as felhasználói adatbázisának területi elemzésével két kulcskérdés megválaszolására törekszik. Egyrészt arra vagyunk kíváncsiak, hogy a településméret miként hat az online közösségi hálók terjedésére (amelyet a teljes népességhez viszonyított felhasználói aránnyal mérünk), illetve a közösségi aktivitás intenzitására (amelyet az átlagos kapcsolatszámmal mérünk). Másrészt arra keresünk választ, hogy az online közösségi hálók terjedése és az online aktivitás miként függ a hálózat középpontjától mint eredetponttól vett földrajzi távolságtól. Feltételezésünk szerint a kibertér és az offline világ helyfüggő jellemzői szimultán meghatározói lehetnek az online közösségi hálók térbeliségének.

\section{A kibertér és az offline földrajz}

Az internet és az egyéb digitális kommunikációs eszközök forradalmi hatású fejlődése az 1990-es évektől a területi kutatói szakma széles köreit a főbb elméleti közelítések és hipotézisek újragondolására sarkallta. Egyre világosabbá vált, hogy a digitális információs interakciók egy önálló és sajátos teret, egy párhuzamos kibertéri világot generálnak, mely azonban nem teljesen független világunk fizikai-térbeli sajátosságaitól (Hayes 1997; Wellman 2001).

A kibertérrel foglalkozó tanulmányok általában sokoldalú és összetett jelenségként közelítenek ehhez a térfogalomhoz, egyesítve az infokommunikáció 
műszaki-technológiai dimenzióit, valamint a felhasználói szokások és tulajdonságok humán oldalait. A kibertér így az információ és a kommunikáció áramlásának egyfajta koncepcionális tereként jellemezhető, amely a digitális világ hardvereszközei, a számítógépek szoftverei, a telekommunikációs hálózatok és az emberi elme szerves kombinációjából jött létre (Devriendt, Derudder, Witlox 2008). Az online és az offline világ kapcsolatait nézve ez a tér virtuális, azaz láthatatlan kreálmány, melyhez valódi anyagi következmények is kapcsolódnak (például valódi áruk kereskedelme a virtuális tér e-kereskedelmi megoldásaiban). Sőt, azt sem felejthetjük el, hogy a kibertér teljes egészében társadalmi eredetű (Mészáros 2003), következésképpen nem független offline világunk társadalmától és annak térbeliségétől.

A kibertérben vizsgálhatjuk az információs társadalom terének fizikai aspektusait megjelenítő hálózati tér (network space) elemeit, amely magában foglalja az internet infrastruktúráját, a száloptikai és müholdas hálózatokat, az adatkommunikáció egyéb technológiai elemeit, vagy például az IP-címekkel reprezentált számítógépeket, szervereket és felhasználókat. Ezek a valódi térbe ágyazódnak (Tranos 2011), a köztük megfigyelt forgalom saját téri rendjét, a hálózati szerveződés törvényszerűségeit követi. Miközben Tranos és Nijkamp (2013) tanulmánya a kibertér ezen szférájában vizsgálódik, addig jelen tanulmányunk a világháló metaforikus kapcsolati terének (a web terének) sajátosságait elemzi, s ebben tesz kísérletet az offline földrajz külső teret befolyásoló szerepének vizsgálatára. Az offline földrajz - a mi olvasatunkban - azon térbeli magyarázatokat adja az online közösségi hálók működésének megértéséhez, amelyek nem a világháló belső müködéséből fakadnak, hanem attól független, külső eredetűek, a hálózatba (direkt értelemben) nem bekapcsoltak. Az offline földrajz magyarázó elemei legújabban épp a közösségi oldalak vizsgálataival kerültek reflektorfénybe - lásd Kulshrestha, Kooti, Nikravesh és Gummadi (2012) vizsgálatait a Twitter-felhasználók interakcióiban felfedezett földrajzi motívumokról - vagy az online tartalmak elemzésében bukkantak fel - lásd például Shelton, Zook és Graham (2012) vizsgálatait az internethasználat és a vallási tartalmak földrajzi összefüggéseiről -, ám ezek a magyarázatok még korántsem adtak választ az online és az offline világ térbeli kapcsolatának minden kérdésére.

A kibertér és az offline földrajz kapcsolatát a vizsgálatunk tárgyát képező online közösségekben is szignifikánsnak várjuk. Az online közösségeket vizsgáló korábbi tanulmányok ugyanis azt hangsúlyozzák, hogy a virtuális világ és a fizikai világ összekötöttségéhez (Benedikt 1991) hasonlóan az internetes közösségek is térbeli, valamint társadalmi megkötöttségűek (Jones 1995). Az online közösségeket kulturális, strukturális, politikai és gazdasági jellemzők konstruálják, melyek földrajzi vonatkozásokkal átszőtt társadalmi kapcsolatokon és intézményeken alapulnak (Fernback 2007). Következésképp az online közösségek kiépülésében a térbeli tényezők (pl. a távolság) is lényeges szerepet játszhatnak. Feltételezhető, hogy minél nagyobb a távolság két, véletlenszerüen kiválasztott egyén között, annál kisebb a valószínűsége, hogy egyazon online közösséghez 
tartoznak. Másrészt viszont amint ezek a személyek ugyanahhoz a közösséghez tartoznak, online viselkedésük is hasonló lehet, függetlenül a köztük lévő földrajzi távolságtól.

A távolság mellett a méret (pl. településméret) és más földrajzi tulajdonságok is meghatározók lehetnek az online közösségek működésében. Az online és offline világ térbeli kapcsolataiban az agglomerációk vagy központi helyek szerepe ráadásul többféleképp ítélhető meg. Az információs eszközök mérséklő és erősítő szerepet is játszhatnak a centripetális és centrifugális hatások eredőjeként kialakuló területi folyamatokban (Krugman 2000). A földrajzi helyválasztás szabadságát képviselők szerint a kommunikációs technológiák lehetővé teszik, hogy a népesség és a gazdasági tevékenység ne kötődjön egyes földrajzi helyekhez, hiszen a telekommunikáció képes a központokon kívüli periferiális helyeket is hálózatba kötni. Az kiberteret ezek a nézetek az üzleti világ nagy kiegyenlítő erejének tekintik, mivel lehetővé teszi a távoli helyek versenybe szállását, akár a nagyvárosi térségekkel szemben is (Gorman 2002). Másrészt viszont az innováció és a tudás termelését továbbra is lokális alapvonások vezérlik a személyes interakciók szükségessége miatt (Feldman 2002), melyek a központi helyeken és az agglomerációkban lehetnek intenzívebbek az információs korban is (Storper, Venables 2004). Az online kommunikáció s benne az online közösségi hálózatok így vélhetően igazodnak az agglomerációs trendekhez, azaz azokat a helyeket preferálják, ahol az emberek nap mint nap nagy gyakorisággal találkoznak. A kibertér és az offline földrajz kapcsolata tehát számos alkérdés kapcsán vizsgálható.

\section{Online közösségi hálózatok tértudományi közelítésben}

A közösségi hálók (Facebook, MySpace, Bebo stb.) sajátosságai iránt az utóbbi években növekvő tudományos érdeklődés mutatkozik (boyd, Ellison, 2007). A kutatások fóárama széles körben vizsgálja többek között a tanulási és kommunikációs folyamatokat (Greenhow 2011), az online identitást (Zhao, Grasmuck, Martin 2008), a fiatalok és a digitális média szerepét (boyd 2008), az online magánéletet (Acquisti, Gross 2009) vagy épp a hálózatok dinamikáját (Kumar, Novak, Tomkins 2006). A földrajz szerepe is megjelent a diszkussziókban, különösképp a felhasználók által generált információk térképezésével (Yardi, boyd, 2010).

Az online közösségi hálók olyan nagyméretű hálózatok, amelyekben a felhasználók képezik a csomópontokat, éleknek pedig a köztük lévő kapcsolatok tekinthetők. A közösségi hálók webalapú szolgáltatások, amelyek lehetővé teszik, hogy a felhasználók láthatóvá tegyék társadalmi kapcsolatrendszerüket (boyd, Ellison 2007). A közösségi hálók az emberek közti kommunikáció kiegészítő formái, mégpedig főként azok között, akik már korábban, a valódi világban is ismerték egymást (Ellison, Steinfield, Lampe 2006, 2007). Másképp fogalmazva, a közösségi oldalak arra is használhatóak, hogy új személyeket ismerjünk meg, azonban döntő többség- 
ben azokkal az emberekkel való kapcsolatainkat dokumentáljuk rajtuk, akikkel az eddigi offline világ hálózataiban kapcsolatba kerültünk. Ezek a kapcsolati hálók viszont, úgy tünik, térbeli megkötöttségeket is mutatnak.

Sőt, a legnagyobb hálózatok (pl. Facebook) fokszámeloszlása nagyon hasonló a való világ társadalmi hálózatainak többszintű viselkedéséhez (Ahn, Han, Kwak, Eom, Moon, Jeong 2007; Ugander, Karrer, Backstrom, Marlow 2011). Más szóval az online közösségi hálózatok egyértelműen különböznek a többi webalapú hálózattól, utóbbiak ugyanis skálafüggetlen fokszámeloszlást követnek, ahol a weboldalak egy kis része a kapcsolatok kimagaslóan nagy számával rendelkezik (Barabási, Albert 1999). Az online közösségi hálózatok a való világ hálózataihoz közelebbinek tűnnek, habár a kiterjedt és mélyreható kutatások az online és az offline társadalmi hálózatok kapcsolatairól lényegében még hiányoznak (Hogan 2009; Traud, Kelsic, Mucha, Porter 2008). Meglátásunk szerint az online közösségi hálók a valódi világ hálózatainak torzult, módosított változatai (Ugander, Karrer, Backstrom, Marlow 2011). Az online közösségi hálózatok kutatásai véleményünk szerint így kapcsolatot teremthetnek a kibergeográfia stock, illetve flow jelenségeinek elemzései között. Csak egy-egy példát említve: a felhasználók közötti kapcsolatok létrejötte a fizikai helyzettől is függhet (hiszen a távolság csökkenti a kapcsolatok kialakulásának valószínűségét), míg a felhasználók csoportokon belüli jelenléte, kommunikációja, megosztásai stb. vélhetően kevésbé kötődnek a térhez (hiszen a kommunikációt segítő online hálózat az offline kapcsolatoktól függetlenül múködhet).

A korábbi geográfiai közelítésű tanulmányok főleg azt vizsgálták, hogy a földrajzi távolság milyen hatást gyakorol az online közösségi hálózatok struktúráira és a kommunikációra. Különösen az alábbi tématerületek vázolhatók fel: 1. a hálózati topológia területi dimenzióinak vizsgálata; 2. a távolságnak a felhasználók által generált információk megosztására gyakorolt hatásainak analízise. A kutatások egy része újabban ugyanakkor azt elemzi, hogy az online közösségi hálókban végzett kommunikációk miképpen befolyásolják a városok szerepéről alkotott képünket, ezért 3. tématerületként a városi geotagek, a felhasználók által generált, földrajzilag lokalizálható információk elemzése is említhető. A kutatások főbb megállapításai az alábbiak szerint foglalhatók össze:

1. A térbeliség meghatározója lehet az online közösségi hálók struktúráinak. Liben-Nowell, Novak, Kumar, Raghavan és Tomkins (2005) a LiveJournal közösségi háló kapcsolatait vizsgálva kimutatták, hogy a kapcsolatok mindössze egyharmada volt független a földrajzi megkötöttségektől. Escher (2007) hasonlóképpen azt találta, hogy az egohálók túlnyomó többsége lokális eredetű. A Facebook-kapcsolatok hatalmas adatbázisaira épülő elemzések ugyancsak kimutatták, hogy a kapcsolatok legnagyobb része országhatáron belül jön létre, és az országok közti kapcsolatok száma is a földrajzi távolságtól függ (Ugander, Karrer, Backstrom, Marlow 2011). 
2. A távolság alapvető jelentőségű a közösségi médiában. A Facebook-, a Livejournal- és a Twitter-kutatások például ún. kisvilágjelenségeket mutattak ki a közösségi hálókban (Liben-Nowell, Novak, Kumar, Raghavan, Tomkins 2005; Yardi, boyd 2010). A kutatások azt valószínűsítik, hogy a lokális hálózatok sűrủbbek, mint a nem lokálisak, de az átlagos hálózati kapcsolat két tetszőleges felhasználó között - bárhol is legyenek -, kicsinek mutatkozik. Sőt, Takhteyev, Gruzd és Wellman (2012) kutatása például rávilágított arra, hogy a földrajzi távolság egyes típusai jelentős hatást gyakorolnak a Twitter hálózatának formálódására. Eredményeik szerint két város között a légi összeköttetések gyakoriságával a városlakók közti Twitter-kapcsolatok száma igen erős korrelációt mutat, miközben a hagyományos kapcsolatok hálózata amúgy regionális és országhatárokkal, valamint nyelvi gátakkal van átszőve.

3. A városi terek az online közösségi hálók jelenlétének domináns terei. Mivel a felhasználók általában valódi helyeken (bárokban, éttermekben, köztereken, irodákban, otthon stb.) fogalmazzák meg hozzászólásaikat, joggal gondolhatunk az online és az offline világ interakcióira, melyben a földrajz hatással van az online kommunikációra, miközben az online kommunikáció szintén formálja a városi tereket (Berg 2011). Phithakkitnukoon és Olivier (2011) az okostelefonokon használható Foursquare-alkalmazások vizsgálatával próbálta a társadalmi aktivitást kategorizálni London, New York és Párizs összehasonlításával. Kutatásaikban a társadalmi kapcsolatok hatványfüggvény-eloszlását mutatták ki, ami azt a gondolatot veti fel, hogy a nagy intenzitású társadalmi aktivitás többnyire egy-két helyen koncentrálódik.

\section{Az iWiW térbeli sajátosságai: empirikus vizsgálatok}

Az iWiW (International who is who) közösségi oldal 2002 áprilisában kezdte meg működését, és rövidesen a legnépszerübb közösségi oldallá vált Magyarországon, 2006-ra pedig a legtöbbet látogatott magyar weboldal lett. Az első években a felhasználók száma korlátozott volt, de 2005-től, az új funkciók bevezetésével a regisztrált felhasználók száma exponenciális növekedésnek indult. 2006 áprilisában, amikor az Origo Zrt. lett az oldal tulajdonosa, a rendszerben 640000 tag 35 millió kapcsolattal volt jelen. Az ezt követő években a regisztrált felhasználók száma tovább növekedett: 2006 decemberére 1,5 millióra, 2008 decemberére pedig több mint 4 millió före.

A közösségi oldalak közti versenyben idővel Magyarországon is a Facebook előretörése volt megfigyelhető. Habár a magyar Facebook-felhasználók száma csak 2011-re érte el a 3 millió föt, a Facebook piaci részesedése továbbra is folyamatosan növekszik, az iWiW-felhasználók stagnálása vagy csökkenése prog- 
nosztizálható (2013 augusztusában Magyarországon kb. 4,6 millió Facebookés kb. 4 millió iWiW-felhasználó adatát tartották számon). A Facebook napi látogatottsága már 2010 októberében meghaladta az iWiW látogatottsági mutatóit.

Az információs társadalom részletesebb hazai területi kutatásai szerint az iWiW-felhasználók számának vizsgálata jó közelítője lehet a magyar internetdiffúzió alakulásának. A felhasználói közösség létszáma gyorsabban növekedett a regionális központokban és a nagyobb településeken, mint a kisebb városokban (Tóth 2012). Továbbá az iWiW-felhasználók aránya a teljes népességen belül erősen korrelál az információs társadalom egyéb területi indikátoraival (pl. az internet- és mobiltelefon-előfizetések számával).

Adatbázisunk 2008. októberi adatokat tartalmaz, amikor a felhasználók és a kapcsolatok száma lényegében minden településre hozzáférhető volt. A felhasználók földrajzi lokalizálásához a regisztrált személyek profiljait használtuk, melyek ugyanakkor alkalmanként problematikusak lehetnek a lokalizációban (Hecht, Hong, Suh, Chi 2011). Az iWiW-en kötelező lokalitást megjelölni, amelyet a felhasználó egy választható listából jelölhet meg. A lakhely ezen adata később könnyen módosítható és természetesen nem kapcsolódik hozzá semmiféle valódi ellenőrzés. Ennélfogva joggal gondolható, hogy a felhasználók lokalizált adatai esetünkben néha torzítottak lehetnek.

Az adatbázisunkban szereplő 3545103 felhasználó adata 2436 település között szóródik. Ismert továbbá a kapcsolatok aggregált száma a településeken, köztük 697-ben egyáltalán nem regisztráltunk iWiW-felhasználót. E települések többsége kicsi vagy aprófalu, bár közülük 128 darab 500 főnél, 23 pedig 1000 fönél népesebb. A további 2436 településnek mind volt legalább 10 iWiW-felhasználója az adatbázisban.

Mélyebb analízisünk két kulcsváltozót vizsgált. Az egyik az iWiW-felhasználók aránya a település teljes népességéhez viszonyítva (USERRATE), amelyet a közösségi háló terjedésének proxyjaként használtunk, a másik az iWiW-kapcsolatok településenkénti átlagos száma (CONNECT), amely a helyi aktivitás szintjének proxyjaként szolgált. A következőkben a településméret (POP), a Budapesttől mint a hálózat eredetpontjától vagy középpontjától való távolság (BPDIST), valamint a kommunikációs infrastruktúra kiépültségi szintjének (COMM) fenti változókra gyakorolt hatásait szemléltetjük. Megjegyezzük, hogy az indikátorok logaritmikusan transzformáltak (a változóleírást az 1. táblázat tartalmazza).

\section{A településméret hatásainak vizsgálata}

A települések népességszáma (POP) szoros összefüggésben van az iWiW-felhasználók arányával (USERRATE), habár szignifikáns számban létezik olyan település is, ahol senki sem használja ezt a közösségi hálót (1. ábra). A pozitív összefüggés főleg a kistelepülések nagyobb szóródása miatt látható jól az ábrán. 
1. ábra: Települési szintű összefüggések az iWiW-felhasználók aránya, a kapcsolatok átlagos száma, valamint a népességszám, a Budapesttől való távolság és a komplex kommunikációs index értékei között, 2008

Settlement level association of $i$ WiW user rate and connectivity with population size, distance from Budapest and the complex communication index, 2008
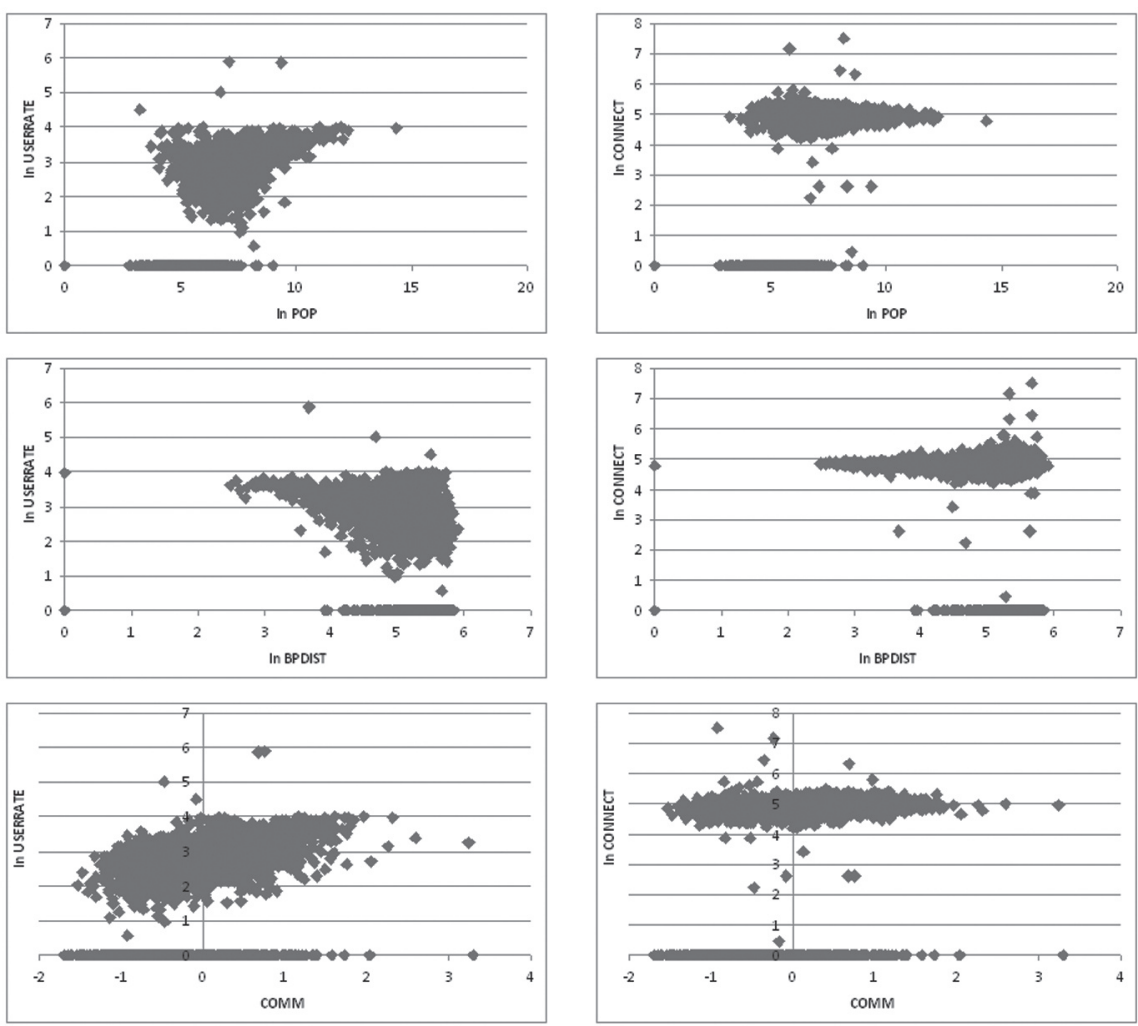

A népesebb települések pontjai ugyanakkor az ábrán vonalszerủen helyezkednek el, amitől csak kivételes esetben látható eltérés.

A népességszám (POP) és a kapcsolatszám (CONNECT) mutatói között szignifikáns összefüggés azonban nem mutatkozott. (Ez az összefüggés csak akkor látszik, ha az iWiW-kapcsolatokkal nem rendelkező településeket kihagyjuk a vizsgálatból. A témára a regressziós modellekkel foglalkozó fejezetben még visszatérünk.) A két log-transzformált változó közötti kapcsolat közel lineáris, habár az ábra bal oldalán nagyobb variancia figyelhető meg. Ez arra utal, hogy a települések nem különböznek a tekintetben, hogy a felhasználók miképpen építik fel kapcsolataikat, ha már a hálózaton belül vannak. Másként fogalmazva a kapcsolatszám változó, avagy az online közösségi hálóban a barátok átlagos száma lényegében független a településmérettől. 
Ezen eredményekből arra lehet következtetni, hogy a vizsgált közösségi háló terjedésének és az aktivitás mutatóinak különböző területi jellemzői vannak. Az online közösségi hálókba való integráltság erősen függ a településmérettől: a kisebb települések relatíve alacsonyabb felhasználói rátával rendelkeznek, mint a nagyobbak. Mindeközben amint a közösségi háló akár a legkisebb helyekre is elér, a felhasználók valószínűleg reagálnak erre, és a nagyobb városokban élőkhöz hasonlóan kezdik felépíteni hálózatukat. Az átlagos felhasználónak közel ugyanannyi kapcsolata van mindkét településtípus esetében. Habár a központi és periferikus helyek eltérőek lehetnek az online közösségi aktivitásban (amelyet a Budapesttől való távolsággal (BPDIST) mutatott összefüggések tükröznek, főleg a nagyobb távolságra lévő településeknél). A kommunikációs infrastruktúra (COMM) szintje pedig, úgy tűnik, inkább a felhasználói aránnyal s kevésbé a kapcsolatszámmal mutat összefüggést.

\section{A távolság hatásának vizsgálata}

A településméret mellett a földrajzi távolságnak is hatása van az online közösségi hálók tulajdonságaira. Az 1. ábra negatív kapcsolatot mutatott a felhasználói arány (USERRATE) és a Budapesttől való távolság (BPDIST) között. Minél nagyobb tehát a távolság, annál nagyobb a valószínűsége az alacsonyabb felhasználói értéknek. Ugyanakkor ez az összefüggés nem jelenik meg a kapcsolatszám (CONNECT) és a fővárostól való távolság mutatói között. A települések szóródása az ábra jobb oldali részén nagyobb, bár egyértelmű elmozdulás nem látszik.

A felhasználói arány és a kapcsolatok átlagos számának területi struktúráját nézve igen érdekes jelenség bontakozik ki. A két változó területi mintázata meglehetősen különbözik, ellentétes területi struktúrájuk van a fővárostól való földrajzi távolsággal összevetve (2a. és $2 b$. ábra). A felhasználói arány magasabb azokon a településekben, amelyek közelebb fekszenek a fővároshoz (ahol az iWiW-hálózat gyökerei találhatók), míg a kapcsolatszám a periferikus területeken tünik magasabbnak. A fővárosi agglomeráció környéke a felhasználói arányban kiemelkedik az ország térképén. Hasonló vonatkozik a Bécs-Budapest-tengely, illetve a Győr környéki területek településeire. Relatíve kiemelkedő továbbá a Balaton környéke és például Pécs környezete is. A főbb regionális és oktatási központok (pl. Szeged, Debrecen, Nyíregyháza, Miskolc) ugyancsak kiemelkednek a környezetükből az ország keleti részén.

Másrészt viszont a periferikus helyzetü települések regisztrált felhasználói valamelyest aktívabbnak tűnnek a centrumtérségekben található társaikkal szemben a hálózatépítésben. A kapcsolatszám láthatóan magasabb a fővárostól távolabbi helyeken. A fővárosi agglomeráció és a keleti regionális központok nem tünnek ki ebben a vonatkozásban (2b. ábra). A két körzet, mely mind a felhasználói arányban, mind a kapcsolatszámban kimagaslik környezetéből, Győr és Pécs. 
2a. ábra: Az iWiW-felhasználók aránya a települések lakosságszámához viszonyítva, 2008 iWiW user rate values by settlements, 2008

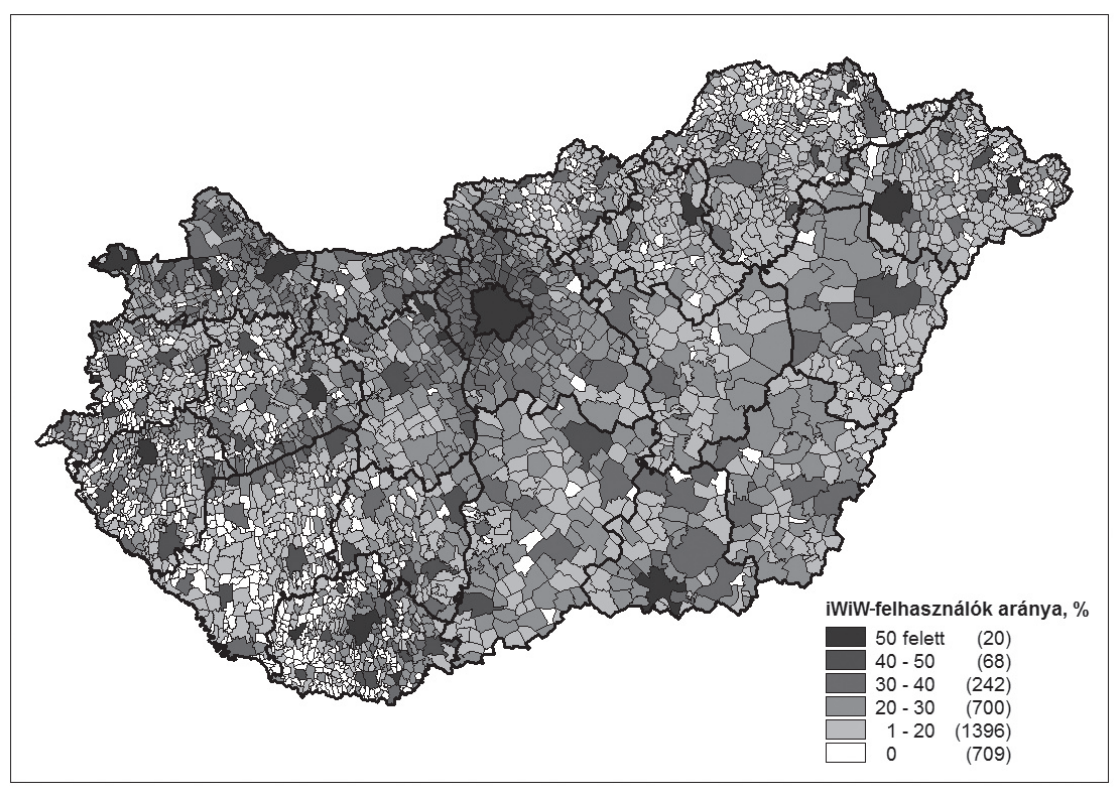

2b. ábra: Az iWiW-kapcsolatok átlagos száma településenként, 2008 iWiW connection values by settlements, 2008

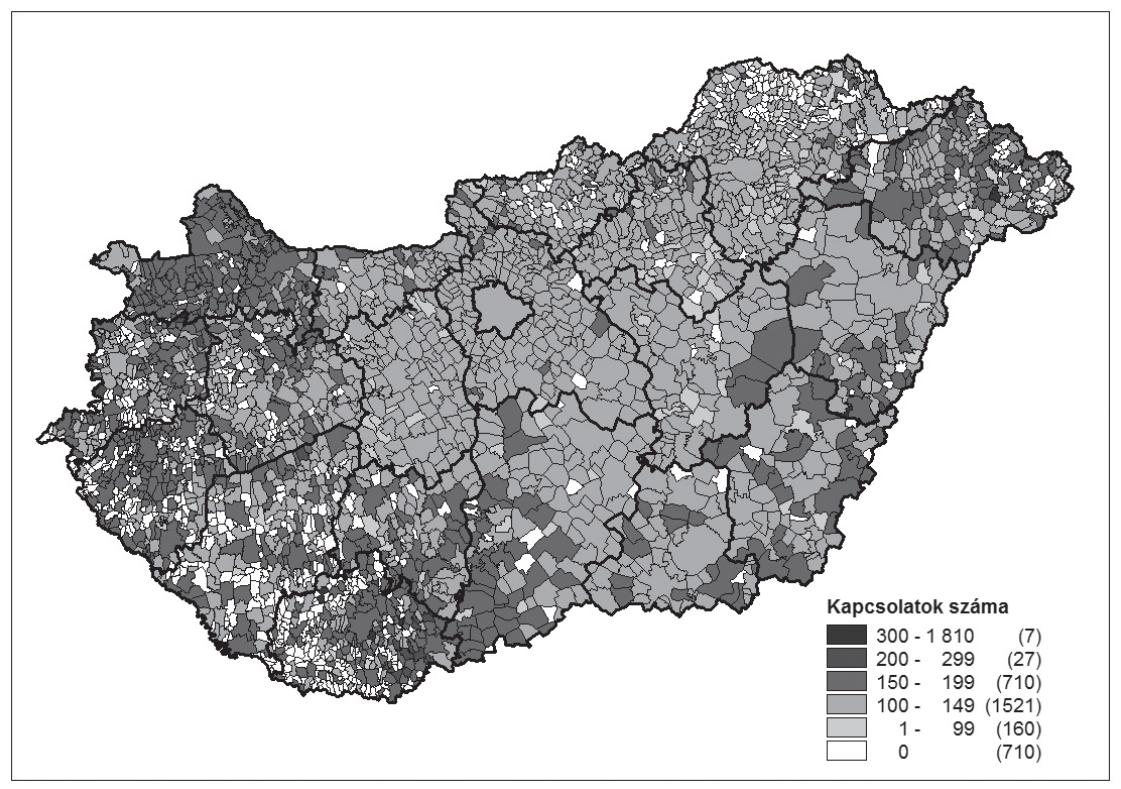


Eredményeink szerint tehát az online közösségi hálók terjedése és az aktivitás területi jellemzői nem feltétlenül esnek egybe. Az online közösségi hálók földrajzának kétarcúsága rajzolódik ki: egyrészt az online közösségi hálók terjedése alapjában véve a földrajzi helyzettől és a központtól való távolságtól függ, másrészt a perifériák felhasználói jóval aktívabbak a hálózatépítésben. Ez utóbbi jelenség magyarázható azzal, hogy a periférián élők vélhetően nagyobb előnyt látnak a közösségi hálók mint kommunikációs platformok használatában. Ugyanakkor az is feltételezhető, hogy az iWiW kezdeti szakaszában a központi helyek lakosai nagyobb kapcsolatszámmal rendelkeztek. Ezért érdekes kérdés, hogy mikor lépett át az iWiW abba az életciklusba, amely az aktivitás jelen tanulmányban bemutatott területi képét mutatja. A felvetést ebben a tanulmányban nem, viszont a kutatás későbbi lépéseiben, a hálózat dinamikus fejlődése kapcsán lesz módunk vizsgálni.

\section{Területi autokorrelációs vizsgálatok}

Az előbb említett távolságfüggés speciális következménye, hogy az elemzés térben szomszédos objektumai társadalmi és gazdasági értelemben is hasonlók lehetnek (Tobler 1970). Ebből következően feltételezhetjük, hogy a földrajzilag szomszédos településeken a felhasználói arány (USERRATE) és a kapcsolatszám (CONNECT) hasonló értékeket mutathat pusztán a relatív földrajzi helyzetből kifolyólag. A következőkben azt vizsgáljuk, hogy a magas értékek vajon tipikusan a szomszédos régiókban találhatók vagy földrajzi értelemben szórtak és véletlen elhelyezkedésüek (a kérdés természetesen ugyanaz az alacsony értékek esetében is).

A szomszédsági hatások kimutatásához először a USERRATE és a CONNECT változók globális autokorrelációs indexeit vizsgáltuk meg. A globális Moran-féle I kiszámításához három különböző területi súlymátrixot használtunk a topologikus és a távolságalapú szomszédsági hatások összehasonlítása érdekében. A területi súlymátrixokat bástyaszomszédság [1], vezérszomszédság [2] és $20 \mathrm{~km}$ sugarú távolságalapú környezeti szomszéd [3] modelljeivel határoztuk meg. A Moran-féle I értékek a USERRATE változó esetében mindhárom modellben szignifikánsan pozitívnak adódtak 0,245 és 0,288 közötti értékekkel (1. táblázat). Valamelyest alacsonyabb, de továbbra is szignifikáns és pozitív eredményeket kaptunk a CONNECT változóra, 0,183 és 0,213 közötti értékekkel. Habár a számítások eredményei távol esnek az erős és magas abszolút értékektől, eredményeink mégis meghatározóak: kimutatható szomszédsági hatás van az adatbázisban. Ugyanakkor indikátorainknál alacsonyabb Moran-I értékeket mértünk, mint más társadalmi-gazdasági indikátorok esetében (pl. népességszám, adófizetői arány, kommunikációs index).

A USERRATE és a CONNECT változók Local Moran indexei a szomszédsági hatások részletesebb megvilágítására adnak lehetőséget. Az ábrák egyértelmü- 


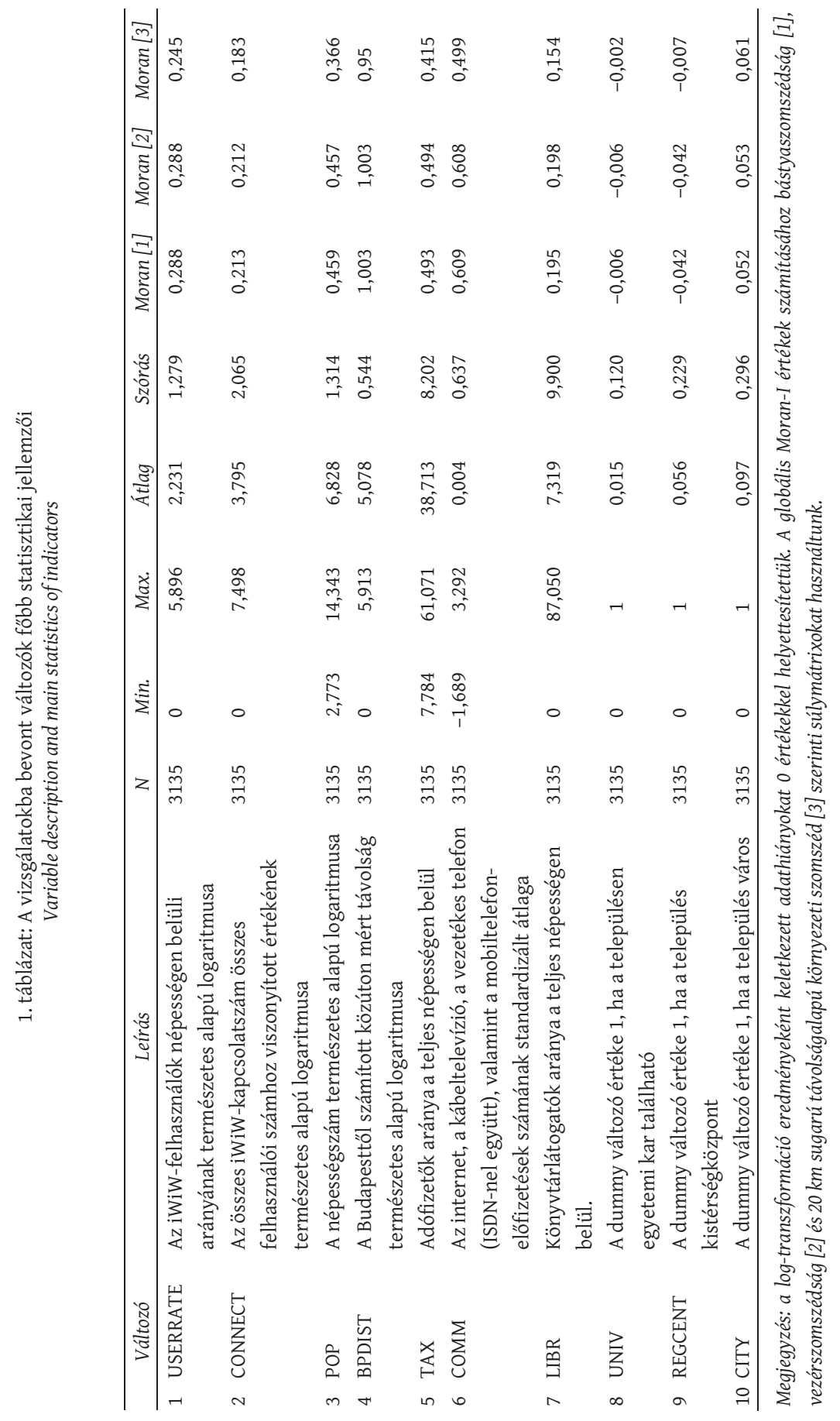




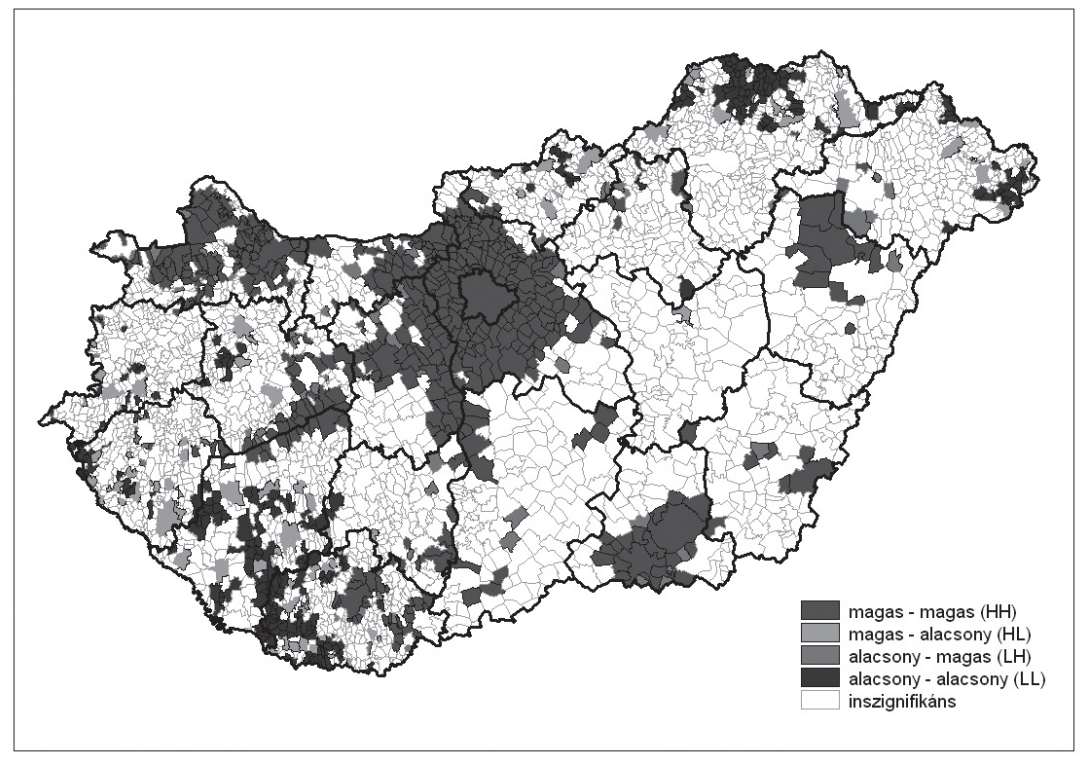

Megjegyzés: a térkép a p=0,05 alatti szignifikáns térségek eredményeit mutatja 999 véletlen permutáció mellett.

en mutatják, hogy a szomszédsági hatások lokálisan igen változatosak, bár az ország egyes részei stabilan klaszterezettek (3a. és 3b. ábra).

A felhasználói arány lokális autokorrelációs mintázata erős klasztereket jelez a fővárosi agglomeráció zónájában, továbbá néhány kisebb, de ugyancsak jól látható klaszterben a regionális központok környezetében (3a. ábra). $\mathrm{Az}$ alacsonyabb értékek tipikusan a délnyugati és az északkeleti periferikus területeken csoportosulnak. A kapcsolatszám lokális autokorrelációs térképe szintén térbeli klasztereződést tükröz, bár az ország középső részén inszignifikáns eredményekkel (3b. ábra). Másrészt viszont nagyon stabil magas értékekkel rendelkező klaszter figyelhető meg az északnyugati országrészben, míg alacsonyabb értékekkel jellemezhető csoportosulások tipikusan ismét a periferikus területeken jellemzőek.

Az eredmények egybeesnek a távolságfüggésre vonatkozó korábbi megállapításainkkal, illetve kiegészítik azokat. Új elemként az autokorrelációs modellek rávilágítottak arra, hogy a távolság e speciális relációja, a szomszédság (illetve a szomszédsági hasonlóság) szignifikánsan jelen lévő tulajdonság az online közösségi hálókban, bár lokálisan eltérő erősséggel. Az agglomerációs hatások szerepe legföképp a főváros és a regionális központok környékén a felhasználói arány területi klasztereződésében mutatkozik meg, miközben az online közösségi aktivitás (az iWiW-kapcsolatszám) klasztereződésében a regionális központok szerepe csekélyebb. 


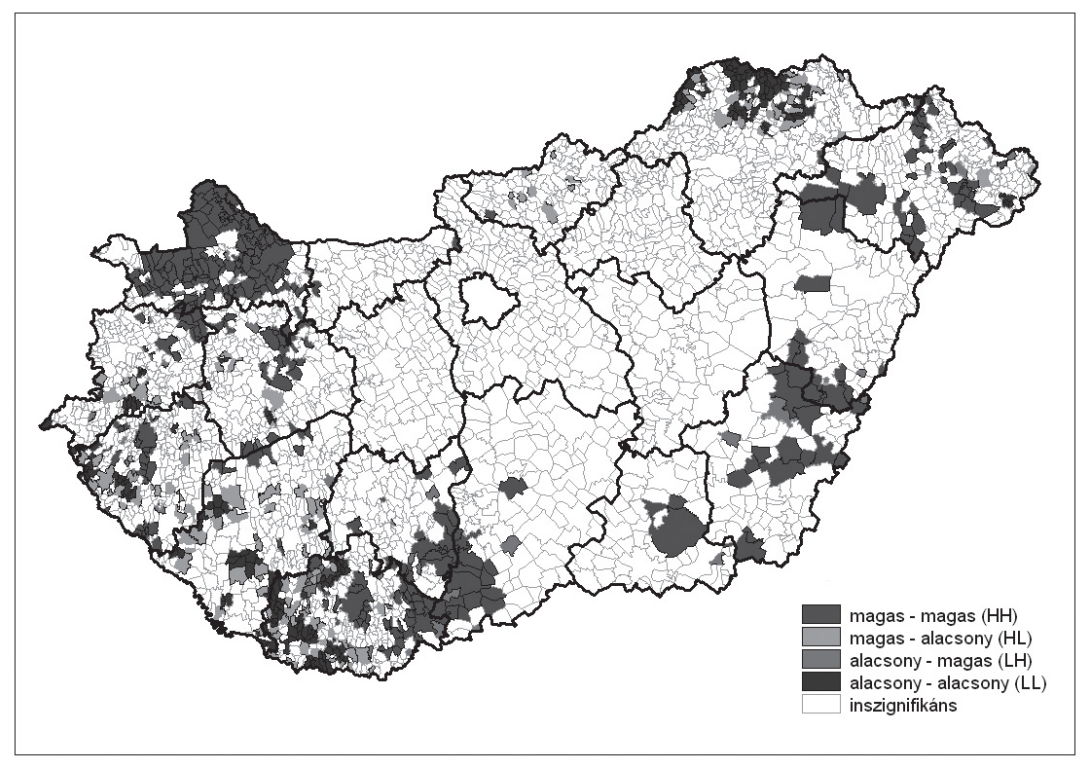

Megjegyzés: a térkép a p=0,05 alatti szignifikáns térségek eredményeit mutatja 999 véletlen permutáció mellett.

\section{Regressziós modellek}

A távolság- és a mérethatások tesztelésére regressziós modellkísérleteket végeztünk, melyekben különböző változókészletekkel elemeztük a fenti két kiemelt tényező magyarázó szerepét. Vizsgálatunkban 3135 magyarországi településre, illetve a 2436 pozitív iWiW-felhasználói számmal rendelkező településre végeztünk OLS és maximum likelihood (ML) regressziós számításokat. Függő változóként a modellekben az iWiW-felhasználók népességen belüli aránya (USERRATE), illetve a kapcsolatok átlagos száma (CONNECT) szerepelt. Magyarázó változónk a népességszám (POP) és a Budapesttől való távolság (BPDIST) volt. Kontrollváltozóként bevontuk a modellbe a regionális fejlettség közelítőjeként az adózói arány (TAX) mutatóját, az IKT-infrastruktúra és -használat komplex mutatóját (COMM), a helyi kulturális aktivitás mutatóit (LIBR, UNIV), valamint a településstruktúra dummy mutatóit (REGCENT, CITY). (Dummy változókat Tranos és Nikkamp 2013 is széleskörüen használt, de a miénktől eltérő céllal. Vizsgálatuk alapvetően nemzetközi szintű, jelen elemzésünk viszont országon belüli, következésképpen más-más távolságmagyarázatokat találhatunk a két írásban.) Mindegyik kontrollváltozónál az online közösségi hálózat területi mutatóival való pozitív kapcsolatot vártunk. A leíró és kontrollváltozók adatai a TeIR adatbázisából származnak. A változók magyarázatai, 
leíró statisztikai jellemzőik, illetve globális autokorrelációs indexeik az 1. táblázatban láthatók.

Pearson-korrelációs vizsgálatainkat a 3135, illetve a 2436 települést tartalmazó csoportra is elvégeztük. Érdekesség, hogy a Budapesttől való távolság és a kapcsolatszám korrelációja fordított előjelű a két adathalmaz vizsgálatában. A kapcsolatszám mutatója magasabb a Budapesthez közelebbi településeken, ha az összes települést figyelembe vesszük. Ugyanakkor ez a változó magas értéket mutat a távolabbi településekben akkor, ha csak a nem nulla értékeket tartalmazó 2436 települést vesszük figyelembe. A korrelációs együtthatók egyetlen mutatópár esetében sem haladják meg a 0,7-es értéket, így regressziós modellünkben vélhetően nem jelentkezik a multikollinearitás torzító hatása (2. táblázat).

A településméretnek és a központtól (Budapesttől) való távolságnak a felhasználók arányára és a kapcsolatok számára gyakorolt hatását két modellhalmazzal teszteltük. Mindkét esetben OLS regressziós modellek demonstrálják a népességnagyság és a fơvárostól való távolság hatásait, mind a teljes településállomány, mind pedig a 2436 iWiW-felhasználóval rendelkező település esetében. Emellett ML spatial error regressziós vizsgálatokat is készítettünk, ahol a területi súlymátrixszal mind a 3135 település szomszédsági hatásait kontrolláltuk.

A felhasználói arány magyarázó modelljeiben a népességnagyság (POP) hatása minden alkalommal pozitívnak és szignifikánsnak bizonyult, míg a Budapesttől való távolság negatív és szignifikáns együtthatókkal volt jellemezhető a legtöbb modellben, habár a szignifikancia eltűnik, ha az egyetemek (UNIV) vagy a településstruktúra (REGCENT, CITY) kontrollváltozóit is bevonjuk a modellbe (3. táblázat). A negatív együttható a Budapesttől való távolság esetében ismét szignifikánssá válik, ha az iWiW-felhasználók nélküli településektől eltekintünk. Az ML térbeli regressziós modellek a népességnagyság változójának

2. táblázat: A vizsgálati változók Pearson-korrelációs összefüggései

Pearson correlation values of variables

\begin{tabular}{llllllllllll}
\hline & \multicolumn{1}{c}{1} & 2 & 3 & 4 & 5 & 6 & 7 & 8 & 9 & 10 \\
\hline 1 & USERRATE & 1 & $0,182^{*}$ & $0,393^{*}$ & $-0,344^{*}$ & $0,569^{*}$ & $0,528^{*}$ & $0,172^{*}$ & $0,238^{*}$ & $0,384^{*}$ & $0,381^{*}$ \\
2 & CONNECT & $0,943^{*}$ & 1 & 0,022 & $0,191^{*}$ & $0,214^{*}$ & $0,150^{*}$ & 0,011 & 0,034 & $0,083^{*}$ & $0,077^{*}$ \\
3 & POP & $0,617^{*}$ & $0,544^{*}$ & 1 & $-0,319^{*}$ & $0,131^{*}$ & $0,149^{*}$ & $0,321^{*}$ & $0,415^{*}$ & $0,564^{*}$ & $0,582^{*}$ \\
4 & BPDIST & $-0,341^{*}$ & $-0,225^{*}$ & $-0,385^{*}$ & 1 & $-0,272^{*}$ & $-0,406^{*}$ & $-0,047$ & $-0,066^{*}$ & $-0,048$ & $-0,101^{*}$ \\
5 & TAX & $0,442^{*}$ & $0,329^{*}$ & $0,224^{*}$ & $-0,294^{*}$ & 1 & $0,677^{*}$ & $-0,003$ & $0,121^{*}$ & $0,167^{*}$ & $0,124^{*}$ \\
6 & COMM & $0,359^{*}$ & $0,235^{*}$ & $0,190^{*}$ & $-0,391^{*}$ & $0,659^{*}$ & 1 & $-0,021$ & $0,209^{*}$ & $0,186^{*}$ & $0,108^{*}$ \\
7 & LIBR & $0,234^{*}$ & $0,195^{*}$ & $0,331^{*}$ & $-0,117^{*}$ & $0,063^{*}$ & 0,031 & 1 & $0,128^{*}$ & $0,232^{*}$ & $0,250^{*}$ \\
8 & UNIV & $0,142^{*}$ & $0,069^{*}$ & $0,361^{*}$ & $-0,078^{*}$ & $0,115^{*}$ & $0,192^{*}$ & $0,124^{*}$ & 1 & $0,464^{*}$ & $0,149^{*}$ \\
9 & REGCENT & $0,251^{*}$ & $0,140^{*}$ & $0,510^{*}$ & $-0,077^{*}$ & $0,169^{*}$ & $0,186^{*}$ & $0,225^{*}$ & $0,467^{*}$ & 1 & $0,618^{*}$ \\
10 & CITY & $0,289^{*}$ & $0,182^{*}$ & $0,547^{*}$ & $-0,139^{*}$ & $0,149^{*}$ & $0,129^{*}$ & $0,247^{*}$ & $0,157^{*}$ & $0,624^{*}$ & 1 \\
\hline
\end{tabular}

Megjegyzés: A nem nulla iWiW-felhasználóval rendelkező 2426 településre vonatkozó korrelációs együtthatók az átló felett, a 3135 településre vonatkozó együtthatók az átló alatt találhatók. Az 1\%-os szinten szignifikáns eredményeket * jelöli. 
3. táblázat: iWiW-terjedés - Az iWiW felhasználói arány (USERRATE) alakulásának regressziós magyarázó modelljei

iWiW spread - regression models for USERRATE

\begin{tabular}{|c|c|c|c|c|c|c|c|c|c|}
\hline & $\begin{array}{l}\text { OLS } \\
{[1]}\end{array}$ & $\begin{array}{l}\text { OLS } \\
{[2]}\end{array}$ & $\begin{array}{l}\text { OLS } \\
{[3]}\end{array}$ & $\begin{array}{l}\text { OLS } \\
{[4]}\end{array}$ & $\begin{array}{l}\text { OLS } \\
{[5]}\end{array}$ & $\begin{array}{l}\text { OLS } \\
{[6]}\end{array}$ & $\begin{array}{l}\text { OLS } \\
{[7]}\end{array}$ & $\begin{array}{l}\text { OLS } \\
{[8]}\end{array}$ & $\begin{array}{c}\text { ML- } \\
\text { Spatial } \\
\text { Error [9] }\end{array}$ \\
\hline POP & $\begin{array}{c}0,556^{* * *} \\
(37,82)\end{array}$ & $\begin{array}{c}0,505^{* * *} \\
(35,14)\end{array}$ & $\begin{array}{c}0,549^{* * *} \\
(36,25)\end{array}$ & $\begin{array}{c}0,568^{* * *} \\
(34,82)\end{array}$ & $\begin{array}{c}0,55^{* * *} \\
(33,28)\end{array}$ & $\begin{array}{c}0,103^{* * *} \\
(13,7)\end{array}$ & $\begin{array}{c}0,065^{* * *} \\
(8,13)\end{array}$ & $\begin{array}{c}0,059^{* * *} \\
(7,4)\end{array}$ & $\begin{array}{c}0,528^{* * *} \\
(31,12)\end{array}$ \\
\hline BPDIST & $\begin{array}{c}-0,285^{* * *} \\
(-8,04)\end{array}$ & $\begin{array}{c}-0,07^{* *} \\
(-2)\end{array}$ & $\begin{array}{l}-0,032 \\
(-0,94)\end{array}$ & $\begin{array}{c}-0,014 \\
(-0,4)\end{array}$ & $\begin{array}{l}-0,049 \\
(-1,39)\end{array}$ & $\begin{array}{c}-0,061^{* * *} \\
(-4,29)\end{array}$ & $\begin{array}{c}-0,09 * * * \\
(-6,25)\end{array}$ & $\begin{array}{c}-0,078^{* * *} \\
(-5,55)\end{array}$ & $\begin{array}{l}0,007 \\
(0,1)\end{array}$ \\
\hline TAX & & $\begin{array}{c}0,041^{* * *} \\
(15,51)\end{array}$ & $\begin{array}{c}0,04^{* * *} \\
(15,1)\end{array}$ & $\begin{array}{c}0,042^{* * *} \\
(15,65)\end{array}$ & $\begin{array}{c}0,042^{* * *} \\
(15,67)\end{array}$ & $\begin{array}{c}0,025^{* * *} \\
(18,58)\end{array}$ & $\begin{array}{c}0,024^{* * *} \\
(18,47)\end{array}$ & $\begin{array}{c}0,024^{* * *} \\
(18,34)\end{array}$ & $\begin{array}{c}0,041^{* * *} \\
(14,38)\end{array}$ \\
\hline COMM & & $\begin{array}{c}0,145^{* * *} \\
(4,05)\end{array}$ & $\begin{array}{c}0,197^{* * *} \\
(5,5)\end{array}$ & $\begin{array}{c}0,183^{* * *} \\
(5,13)\end{array}$ & $\begin{array}{c}0,153^{* * *} \\
(4,31)\end{array}$ & $\begin{array}{c}0,16^{* * *} \\
(9,35)\end{array}$ & $\begin{array}{c}0,144^{* * *} \\
(8,63)\end{array}$ & $\begin{array}{c}0,161^{* * *} \\
(9,83)\end{array}$ & $\begin{array}{c}0,195^{* * *} \\
(4,95)\end{array}$ \\
\hline LIBR & & $\begin{array}{c}0,005^{* * *} \\
(2,91)\end{array}$ & $\begin{array}{c}0,005^{* * *} \\
(3,03)\end{array}$ & $\begin{array}{c}0,006^{* * *} \\
(3,51)\end{array}$ & $\begin{array}{c}0,005^{* * *} \\
(3,37)\end{array}$ & $\begin{array}{c}0,004^{* * *} \\
(5,7)\end{array}$ & $\begin{array}{c}0,004^{* * *} \\
(5,13)\end{array}$ & $\begin{array}{c}0,004^{* * *} \\
(4,92)\end{array}$ & $\begin{array}{c}0,004^{* * *} \\
(2,13)\end{array}$ \\
\hline UNIV & & & $\begin{array}{c}-1,241^{* * *} \\
(-8,4)\end{array}$ & & & $\begin{array}{l}0,107^{*} \\
(1,79)\end{array}$ & & & $\begin{array}{c}-1,116^{* * *} \\
(-7,78)\end{array}$ \\
\hline REGCEN & & & & $\begin{array}{c}-0,666^{* * *} \\
(-7,85)\end{array}$ & & & $\begin{array}{c}0,33^{* * *} \\
(9,56)\end{array}$ & & \\
\hline CITY & & & & & $\begin{array}{c}-0,362^{* * *} \\
(-5,42)\end{array}$ & & & $\begin{array}{c}0,297 * * * \\
(11,18)\end{array}$ & \\
\hline W & & & & & & & & & $\begin{array}{c}0,554^{* * *} \\
(11,62)\end{array}$ \\
\hline CONS & $\begin{array}{l}-0,115 \\
(-0,48) \\
\end{array}$ & $\begin{array}{c}-2,517^{* * *} \\
(-10,21)\end{array}$ & $\begin{array}{c}-2,933^{* * *} \\
(-11,78)\end{array}$ & $\begin{array}{c}-3,194^{* * *} \\
(-12,33)\end{array}$ & $\begin{array}{c}-2,911^{* * *} \\
(-11,37)\end{array}$ & $\begin{array}{c}1,384^{* * *} \\
(12,21)\end{array}$ & $\begin{array}{c}1,802^{* * *} \\
(15,23)\end{array}$ & $\begin{array}{c}1,788^{* * *} \\
(15,63)\end{array}$ & $\begin{array}{c}-2,998^{* * *} \\
(-7,88) \\
\end{array}$ \\
\hline $\mathrm{N}$ & 3,135 & 3,135 & 3,135 & 3,135 & 3,135 & 2,426 & 2,426 & 2,426 & 3,135 \\
\hline$R^{2}$ & 0,393 & 0,484 & 0,495 & 0,494 & 0,488 & 0,466 & 0,485 & 0,492 & 0,516 \\
\hline F-teszt & $1014,8^{* * *}$ & $585^{* * *}$ & $510,9^{* * *}$ & $508^{* * *}$ & $497,6^{* * *}$ & $351,9^{* * *}$ & $379,4^{* * *}$ & $389,9 * * *$ & \\
\hline VIF & 1,17 & 1,5 & 1,49 & 1,57 & 1,57 & 1,53 & 1,64 & 1,62 & \\
\hline \multicolumn{10}{|l|}{ LM-Error } \\
\hline Bástya & $76,049^{* * *}$ & $14,892^{* * *}$ & $15,797^{* * *}$ & $26,019^{* * *}$ & $21,489^{* * *}$ & & & & \\
\hline Vezér & $76,672^{* * *}$ & $14,398^{* * *}$ & $15,209^{* * *}$ & $25,672^{* * *}$ & $21,106^{* * *}$ & & & & \\
\hline Távolság & $507,34^{* * *}$ & $87,002^{* * *}$ & $83,049^{* * *}$ & $90,153^{* * *}$ & $87,935^{* * *}$ & & & & \\
\hline \multicolumn{10}{|l|}{ LM-Lag } \\
\hline Bástya & 0,114 & $4,802^{* *}$ & $2,849^{*}$ & 0,188 & 1,571 & & & & \\
\hline Vezér & 0,081 & $5,191^{* *}$ & $3,184^{*}$ & 0,255 & 1,766 & & & & \\
\hline Távolság & 0,501 & $22,202^{* * *}$ & $17,342^{* * *}$ & $10,402^{* * *}$ & $17,195^{* * *}$ & & & & \\
\hline
\end{tabular}

LR-Error $103,366^{* * *}$

Megjegyzés: Az együtthatók alatt zárójelekben az OLS regressziók esetében a t-statisztika eredményeket (1-8. modell), a spatial error regresszió esetében a z-értékeket (9. modell) közöljük. A ***, ** és * jelölések az 1\%-os, 5\%-os és 10\%-os szinten szignifikáns eredményeket jelölik. Az F-teszt nullhipotézise, hogy minden együttható nulla. A területi súlymátrix a 20 km-es küszöbtávolság módszerével készült. 
erős hatását jelzik, de a fővárostól való távolság együtthatója inszignifikánsnak mutatkozik. Összességében a modellek többsége arra utal, hogy minél közelebb van egy település Budapesthez és minél nagyobb, annál magasabb az iWiW-felhasználók aránya az össznépességhez képest.

A kapcsolatszám (CONNECT) nagyságának alakulására a népességszám (POP) erős pozitív és szignifikáns hatással van, ha az összes települést a modellben tartjuk (1-5. modell). Ugyanakkor a népességszám változójának magyarázóereje lezuhan az iWiW-felhasználók nélküli települések regressziós modellből való kihagyásakor (6-8. modell) (4. táblázat). A Budapesttől való távolság hatása sokkal stabilabb: ez a változó fontos szerepet játszik az online közösségi aktivitásban, a településállomány halmazától függetlenül. Ez utóbbi változó pozitív és szignifikáns értékei arra engednek következtetni, hogy minél nagyobb a földrajzi távolság a hálózat központjától, annál nagyobb a felhasználók aktivitása az online közösségi hálókban való kapcsolatépítésben. Ezt a megállapítást nem módosítja az ML spatial error modell sem (9. modell).

Mindkét függő változónknál ugyanazokkal a kontrollváltozókkal dolgoztunk a regressziós modellekben. A felhasználói arány regressziós modelljeiben az összes kontrollváltozó esetében pozitívak és szignifikánsak az együtthatók, kivéve a települési struktúrát jellemző dummy változóknál (UNIV, REGCENT, CITY). Ez utóbbi kontrollváltozóknak negatív hatásai vannak, ha az összes település szerepel a modellben (3-5. modell a 3. táblázatban), míg a változók pozitív hatásúak, ha a nulla iWiW felhasználói számmal rendelkező településeket kihagyjuk a vizsgálatból (6-8. modell a 3. táblázatban). Mivel UNIV, REGCENT és CITY dummy változóink határozott számú település esetében mutatnak 1-es értéket (sorban 46, 168 és 304 esetben), a 3-5. modellekben a nulla iWiW felhasználói számmal rendelkező települések erős torzító hatásával lehet számolni. Ezzel egyidejűleg a 6-8. modellek együtthatóinak pozitív előjelei arra utalnak, hogy a településstruktúra fontos szerepet játszik az online közösségi hálók terjedésében. Ez a hatás nem figyelhető meg a kapcsolatszám 4. táblázatban közölt regressziós modelljeiben. A TAX, COMM és LIBR változóknak szintén pozitív hatása van a felhasználói arány és a kapcsolatszám függő változóira, és a legtöbb esetben ez a hatás szignifikáns.

Összegezve, az OLS és a térbeli regressziós modellek kontrollváltozók bevonása után is igazolták az empirikus fejezet korábbi részeiben bemutatott feltételezéseinket: a földrajzi elhelyezkedés némiképp ellentétes irányú hatásait sikerült bizonyítani a közösségi hálók használatának két aspektusában. A Budapesttől való távolság negatív hatással van a felhasználói arányra, míg pozitív hatással a kapcsolatszámra. Ez másképpen azt jelenti, hogy egyrészt a felhasználói arány csökken a fővárostól való távolság növekedésével, másrészt viszont a felhasználóknak, úgy tűnik, több kapcsolata van a periferikus településeken. 
4. táblázat: iWiW-aktivitás - Az iWiW kapcsolatok átlagos száma (CONNECT) alakulásának regressziós magyarázó modelljei $i$ WiW activity - regression models for CONNECT

\begin{tabular}{|c|c|c|c|c|c|c|c|c|c|}
\hline & $\begin{array}{l}\text { OLS } \\
{[1]}\end{array}$ & $\begin{array}{l}\text { OLS } \\
{[2]}\end{array}$ & $\begin{array}{l}\text { OLS } \\
{[3]}\end{array}$ & $\begin{array}{l}\text { OLS } \\
{[4]}\end{array}$ & $\begin{array}{l}\text { OLS } \\
{[5]}\end{array}$ & $\begin{array}{l}\text { OLS } \\
{[6]}\end{array}$ & $\begin{array}{l}\text { OLS } \\
{[7]}\end{array}$ & $\begin{array}{l}\text { OLS } \\
{[8]}\end{array}$ & $\begin{array}{c}M L- \\
\text { Spatial } \\
\text { Error [9] }\end{array}$ \\
\hline POP & $\begin{array}{l}0,843^{* * *} \\
(33,04)\end{array}$ & $\begin{array}{l}0,787^{* * *} \\
(30,05)\end{array}$ & $\begin{array}{l}0,887^{* * *} \\
(32,36)\end{array}$ & $\begin{array}{l}0,975^{* * *} \\
(33,42)\end{array}$ & $\begin{array}{l}0,946^{* * *} \\
(31,81)\end{array}$ & $\begin{array}{c}0,022^{* * *} \\
(4,12)\end{array}$ & $\begin{array}{c}0,019^{* * *} \\
(3,26)\end{array}$ & $\begin{array}{c}0,013^{* *} \\
(2,24)\end{array}$ & $\begin{array}{l}0,947^{* * *} \\
(28,75)\end{array}$ \\
\hline BPDIST & $\begin{array}{l}-0,071 \\
(-1,14)\end{array}$ & $\begin{array}{c}0,145^{* *} \\
(2,28)\end{array}$ & $\begin{array}{l}0,23^{* * *} \\
(3,66)\end{array}$ & $\begin{array}{c}0,313^{* * *} \\
(4,96)\end{array}$ & $\begin{array}{c}0,22^{* * *} \\
(3,5)\end{array}$ & $\begin{array}{c}0,155^{* * *} \\
(15,1)\end{array}$ & $\begin{array}{l}0,153^{* * *} \\
(14,65)\end{array}$ & $\begin{array}{l}0,15^{* * *} \\
(14,68)\end{array}$ & $\begin{array}{c}0,382^{* * *} \\
(3,45)\end{array}$ \\
\hline TAX & & $\begin{array}{l}0,056^{* * *} \\
(11,38)\end{array}$ & $\begin{array}{l}0,052^{* * *} \\
(10,87)\end{array}$ & $\begin{array}{l}0,056^{* * *} \\
(11,67)\end{array}$ & $\begin{array}{l}0,057^{* * *} \\
(11,76)\end{array}$ & $\begin{array}{c}0,007^{* * *} \\
(7,69)\end{array}$ & $\begin{array}{c}0,007^{* * *} \\
(7,8)\end{array}$ & $\begin{array}{c}0,007^{* * *} \\
(7,7)\end{array}$ & $\begin{array}{l}0,055^{* * *} \\
(10,92)\end{array}$ \\
\hline COMM & & $\begin{array}{l}0,029 \\
(0,44)\end{array}$ & $\begin{array}{l}0,149^{* *} \\
(2,29)\end{array}$ & $\begin{array}{l}0,145^{* *} \\
(2,27)\end{array}$ & $\begin{array}{c}0,06 \\
(0,94)\end{array}$ & $\begin{array}{c}0,064^{* * *} \\
(5,21)\end{array}$ & $\begin{array}{c}0,059^{* * *} \\
4,95\end{array}$ & $\begin{array}{c}0,588^{* * *} \\
(4,91)\end{array}$ & $\begin{array}{l}0,164^{* *} \\
(2,35)\end{array}$ \\
\hline LIBR & & $\begin{array}{l}0,004 \\
(1,29)\end{array}$ & $\begin{array}{l}0,065 \\
(1,42)\end{array}$ & $\begin{array}{c}0,007^{* *} \\
(2,31)\end{array}$ & $\begin{array}{c}0,007^{* *} \\
(2,22)\end{array}$ & $\begin{array}{c}0 \\
(0,2)\end{array}$ & $\begin{array}{c}0 \\
(0,22)\end{array}$ & $\begin{array}{c}0 \\
(0,07)\end{array}$ & $\begin{array}{l}0,004 \\
(1,12)\end{array}$ \\
\hline UNIV & & & $\begin{array}{l}-2,833^{* * *} \\
(-10,59)\end{array}$ & & & $\begin{array}{c}-0,077^{*} \\
(-1,81)\end{array}$ & & & \\
\hline REGCEN & & & & $\begin{array}{l}-2,009^{* * *} \\
(-13,23)\end{array}$ & & & $\begin{array}{l}-0,008 \\
(-0,31)\end{array}$ & & $\begin{array}{l}-1,872^{* * *} \\
(-12,45)\end{array}$ \\
\hline CITY & & & & & $\begin{array}{l}-1,277^{* * *} \\
(-10,64)\end{array}$ & & & $\begin{array}{c}0,03 \\
(1,56)\end{array}$ & \\
\hline W & & & & & & & & & $\begin{array}{l}0,523^{* * *} \\
(10,54)\end{array}$ \\
\hline CONS & $\begin{array}{c}-1,609^{* * *} \\
(-3,88)\end{array}$ & $\begin{array}{c}-4,507^{* * *} \\
(-10,3)\end{array}$ & $\begin{array}{l}-5,457^{* * *} \\
(-12,11)\end{array}$ & $\begin{array}{l}-6,551^{* * *} \\
(-14,13)\end{array}$ & $\begin{array}{l}-5,899^{* * *} \\
(-12,81)\end{array}$ & $\begin{array}{l}3,665^{* * *} \\
(45,44)\end{array}$ & $\begin{array}{l}3,69^{* * *} \\
(43,07)\end{array}$ & $\begin{array}{l}3,749^{* * *} \\
(44,96)\end{array}$ & $\begin{array}{c}-6,679^{* * *} \\
(-9,88)\end{array}$ \\
\hline $\mathrm{N}$ & 3,135 & 3,135 & 3,135 & 3,135 & 3,135 & 2,426 & 2,426 & 2,426 & 3,135 \\
\hline$R^{2}$ & 0,296 & 0,342 & 0,365 & 0,377 & 0,365 & 0,128 & 0,127 & 0,128 & 0,399 \\
\hline F-teszt & $658,59^{* * *}$ & $325,97^{* * *}$ & $299,97^{* * *}$ & $315,94^{* * *}$ & $300,27^{* * *}$ & $59,38^{* * *}$ & $58,77^{* * *}$ & 59,22 & \\
\hline VIF & 1,17 & 1,5 & 1,49 & 1,57 & 1,57 & 1,53 & 1,64 & 1,62 & \\
\hline LM-Error & & & & & & & & & \\
\hline Bástya & $9,871^{* * *}$ & 0,899 & 1,151 & $10,902^{* * *}$ & $6,485^{* *}$ & & & & \\
\hline Vezér & $9,696^{* * *}$ & 0,73 & 0,939 & $10,647^{* * *}$ & $6,219^{* *}$ & & & & \\
\hline $\begin{array}{l}\text { Távolság } \\
\text { LM-Lag }\end{array}$ & $177,17^{* * *}$ & $48,738^{* * *}$ & $46,025^{* * *}$ & $62,553^{* * *}$ & $46,638^{* * *}$ & & & & \\
\hline Bástya & $5,238^{* *}$ & $13,771^{* * *}$ & $10,818^{* * *}$ & 0,957 & $4,006^{* *}$ & & & & \\
\hline Vezér & $5,544^{* *}$ & $14,465^{* * *}$ & $11,503^{* * *}$ & 1,069 & $4,272^{* *}$ & & & & \\
\hline Távolság & $4,633^{* *}$ & $31,196^{* * *}$ & $25,473^{* * *}$ & $9,75^{* * *}$ & $22,338^{* * *}$ & & & & \\
\hline LR-Error & & & & & & & & & $87,654^{* * *}$ \\
\hline
\end{tabular}

Megjegyzés: Az együtthatók alatt zárójelekben az OLS regressziók esetében a t-statisztika eredményeket (1-8. modell), a spatial error regresszió esetében a z-értékeket (9. modell) közöljük. A *** ** és* jelölések az 1\%-os, 5\%-os és 10\%-os szinten szignifikáns eredményeket jelölik. Az F-teszt nullhipotézise, hogy minden együttható nulla. A területi súlymátrix a 20 km-es küszöbtávolság módszerével készült. 


\section{Összegzés}

Vizsgálatunk során ellentmondásos eredményre jutottunk a hálózat középpontjától való távolság felhasználói viselkedésre gyakorolt hatásáról, ami még nem oszlatott el minden bizonytalanságot a távolság kibertérbeli szerepéről és hatásairól. Bizonyítottuk ugyanakkor, hogy a távolság fogalma jelen van e világ keretei között is. Az online közösségi hálók elemzése összességében új betekintést nyújthat az online aktivitásba, és lehetővé teheti, hogy tovább lehessen haladni a távolság halálának vitájában (Tranos, Nijkamp 2013), kihasználva például, hogy az online közösségi hálók adatbázisai egyidejűleg stock és flow adatokat is magukban foglalnak.

Elemzésünk másik fó irányvonala, a méret és az agglomerációk szerepének vizsgálata is a földrajzi szempontok jelenlétét igazolta az offline-online összehasonlításokban, a települések és az ott lakók tulajdonságainak elemzésével. A települési szint magától értetődő és szükségszerü terepe az online közösségi hálók vizsgálatának. Az online közösségi szolgáltatások ugyanis általában városi térségekben keletkeznek, így a városok a terjedés kiindulópontjai, és később is ezek maradnak az elsődleges területei a hálózatba foglalt elemeknek. Vizsgálataink arra is utaltak, hogy minél nagyobb a településméret, annál több a regisztrált felhasználó az ilyen rendszerekben. Másrészt viszont az online aktivitás, amelyet a közösségi hálókban lévő barátok száma vagy a kapcsolatszám jelenít meg, úgy tünik, sokkal kevésbé függ a településmérettől. Összességében az agglomerációk kutatásába új betekintést nyújthat az online közösségi hálók adatainak feldolgozása. Az online közösségi hálók adatai például a diverzitás új mérési dimenzióit és vizsgálható attribútumait (pl. privát háttér, foglalkozás, érdeklődési terület stb.) fogalmazhatják meg a hálózatok területi struktúrájáról.

\section{Köszönetnyilvánítás}

Jakobi Ákos munkáját az MTA Bolyai János Kutatási Ösztöndíja támogatta. Lengyel Balázs az IBS Research Grant támogatásában részesült. A szerzők köszönetüket fejezik ki Vityi Dorottyának az adatgyüjtésben nyújtott segítségéért.

\section{Irodalom}

Acquisti, A., Gross, R. (2009): Predicting social security numbers from public data. Proceedings of the National Academy of Sciences, 27., 10975-10980.

Ahn, Y-Y., Han, S., Kwak, H., Eom, Y-H., Moon, S., Jeong H. (2007): Analysis of topological characteristics of huge online social networking services. Proceedings of the 16th international conference on world wide web. http://citeseerx.ist.psu.edu/viewdoc/down (Letöltés: 2012. november 20.)

Barabási, A. L., Albert, R. (1999): Emergence of scaling in random networks. Science, 286., 509-512. 
Benedikt, M. (1991): Cyberspace: some proposals. In: Benedikt, M. (ed.): Cyberspace: first steps. MIT, Cambridge, 119-224.

Berg, M. (2011): Checking in at the urban playground: digital geographies and electronic flâneurs. In: Comunello, F. (ed.): Networked sociability and individualism: technology for personal and professional relationships. IGI Global, Hershey, 169-194.

boyd, d. (2008): Why youth social network sites: the role of networked publics in teenage social life. In: Buckingham, D. (ed.): Youth, identity, and digital media. The MIT Press, Cambridge, 119-142.

boyd, d., Ellison, N. B. (2007): Social network sites: definition, history, and schoralship. Journal of Computer Mediated Communication, 13., Article 1. http://jcmc.indiana.edu/vol13/issue1/boyd.ellison.html (Letöltés: 2012. november 20.)

Cairncross, F. (1997): The death of distance. How the communication revolution will change our lives. Harvard Business School Press, Boston

de Blij, H. (2007): Why geography matters. Oxford University Press, Oxford

Devriendt, L., Derudder, B., Witlox, F. (2008): Cyberplace and cyberspace: two approaches to analyzing digital intercity linkages. Journal of Urban Technology, 2., 5-32.

Ellison, N., Steinfield, C., Lampe, C. (2006): Spatially bounded online social networks and social capital: the role of Facebook. Elöadás az Annual Conference of the International Communication Association-on, Drezda, Németország, 2006. június 19-23.

Ellison, N., Steinfield, C., Lampe, C. (2007): The benefits of Facebook "friends": social capital and college students' use of online social network sites. Journal of Computer-Mediated Communication, 12. $1143-1168$.

Escher, T. (2007): The geography of online social networks. Előadás 2007. szeptember 5-én. http://people.oii.ox.ac.uk/escher/wp-content/uploads/2007/09/Escher_York_presentation.pdf (Letöltés: 2013. január 7.)

Feldman, M. P. (2002): The internet revolution and the geography of innovation. International Social Science Journal, 171., 47-56.

Fernback, J. (2007): Beyond the diluted community concept: a symbolic interactionist perspective on online social relations. New Media Society, 1., 49-69.

Forman, C., Goldfarb, A., Greenstein, S. (2005): How did location affect adoption of the commercial Internet? Global village vs. urban leadership. Journal of Urban Economics, 3., 389-420.

Gorman, S. P. (2002): Where are the web factories: the urban bias of e-business location. Tijdschrift voor Economische en Sociale Geografie, 5., 522-536.

Greenhow, C. (2011): Learning and social media: what are the interesting questions for research? International Journal of Cyber Behavior, Psychology and Learning, 1., 36-50.

Hayes, B. (1997): The infrastructure of the information infrastructure. American Scientist, 3., 214-218.

Hecht, B., Hong, L., Suh, B., Chi, E. H. (2011): Tweets from Justin Bieber's heart: the dynamics of the "location" field in user profiles. Proceedings of the ACM Conference on Human Factors in Computing Systems (CHI 2011). ACM Press, New York, 237-246.

Hogan, B., (2009): A comparison of on and offline networks through the Facebook API. Working paper http://papers.ssrn.com/sol3/papers.cfm?abstract id=1331029 (Letöltés: 2013 . január 5.)

Jones, S. G. (1995): Understanding community in the information age. In: Jones, S. G. (ed.): Cybersociety: computer-mediated communication and community. Sage, London, 10-35.

Krugman, P. (2000): A földrajz szerepe a fejlődésben. Tér és Társadalom, 4., 1-21.

Kumar, R., Novak, J., Tomkins, A. (2006): Structure and evolution of online social networks. Proceedings of 12th International Conference on Knowledge Discovery in Data Mining. ACM Press, New York, 611-617.

Kulshrestha, J., Kooti, F., Nikravesh, A., Gummadi, K. (2012): Geographic dissection of the twitter network. Max Planck Institute for Software Systems (MPI-SWS). http://www.mpi-sws.org/ farshad/ geographic_dissection.pdf (Letöltés: 2013. december 15.)

Liben-Nowell, D., Novak, J., Kumar, R., Raghavan, P., Tomkins A. (2005): Geographic routing in social networks, Proceedings of the National Academy of Sciences of USA, 102., 11623-11628. www.pnas.org/cgi/doi/10.1073/pnas.0503018102

Mészáros R. (2003): Kibertér. A földrajzi tudás új dimenziói. Hispánia Kiadó, Szeged 
Nijkamp, P. (2012): The death of distance revisited: cyber-place and proximities - A test on quantitative patterns. Előadás a Magyar Regionális Tudományi Társaság 2012. évi vándorgyűlésén. Győr, 2012. november 22. http://www.mrtt.hu/ hu/v2012gyor.html (Letöltés: 2013. február 1.)

Phithakkitnukoon, S., Olivier, P. (2011): Sensing urban social geography using online social networking data. Association for the Advancement of Artificial Intelligence. www.aaai.org (Letöltés: 2013. január 5.)

Shelton, T., Zook, M., Graham, M. (2012): The technology of religion: mapping religious cyberscapes. The Professional Geographer, 4., 602-617.

Storper, M., Venables, A. (2004): Buzz: face-to-face contact and the urban economy. Journal of Economic Geography, 4., 351-370.

Takhteyev, Y., Gruzd, A., Wellman, B. (2012): Geography of Twitter networks. Social Networks, 1., 73-81.

Tobler, W. A. (1970): Computer model simulating urban growth in the Detroit region. Economic Geography, 2., 234-240.

Tóth P. (2012): Magyar települések az információs társadalomban. Doktori étekezés, Széchenyi István Egyetem, Győr.

Tranos, E. (2011): The topology and the emerging urban geographies of the Internet backbone and aviation networks in Europe: a comparative study. Environment and Planning A, 2., 378-392.

Tranos, E., Nijkamp, P. (2013): A távolság halálának új vizsgálata: kiberhely, földrajzi és kapcsolati közelség. Tér és Társadalom, 3., 3-27.

Traud A., Kelsic E., Mucha P., Porter M. (2008): Community structure in online collegiate social networks. E-print arXiv:0809.0690v2

Ugander, J., Karrer, B., Backstrom, L., Marlow, C. (2011): The anatomy of the Facebook social graph. E-print arXiv:1111.4503v1

Wellman, B. (2001): Phisical place and cyberplace: the rise of personalized networking. International Journal of Urban and Regional Research, 2., 227-252.

Yardi, S., boyd, d. (2010): Tweeting from the town square: measuring geographic local networks. Proceedings of the International Conference on Weblogs and Social Media. Washington DC., 2010. május 23-26.

Zhao, S., Grasmuck, S., Martin, J. (2008): Identity construction on Facebook: digital empowerment in anchored relationships. Computers in Human Behavior, 5., 1816-1836. 